\title{
Prototipe Sistem Parkir Gantung Berputar Ke Atas Berbasis Programmable Logic Control Dilengkapi Human Machine Interface
}

\author{
Agus Supardi, Muhammad Sadam Husien \\ Program Studi Teknik Elektro \\ Universitas Muhammadiyah Surakarta \\ Surakarta, Indonesia \\ Agus.Supardi@ums.ac.id
}

\begin{abstract}
Abstraksi-Meningkatnya ekonomi masyarakat semakin menambah jumlah mobil pribadi yang digunakan sebagai alat transportasi. Kekurangan lahan parkir mobil merupakan salah satu masalah parkir di instansi pemerintahan dan swasta. Penelitian ini bertujuan untuk membuat sebuah prototipe sistem parkir gantung berputar ke atas. Sistem parkir ini berbasis PLC (Programable Logic Control) sebagai kendali utama dengan penambahan HMI (Human Machine Interface) sebagai tampilan penghubung antara manusia dan mesin. Bahasa pemrograman yang digunakan adalah ladder diagram yang dibuat dengan menggunakan perangkat lunak CX-Programmer dan NBDesigner. Prototipe sistem parkir yang dirancang mempunyai memiliki 6 slot tempat parkir, terdapat 1 pintu masuk dan memiliki lampu indikator untuk mengetahui tempat parkir dalam keadaan kosong atau penuh. Prototipe ini dibuat dengan menggunakan kerangka besi holo berdiameter 1,5 x $3 \mathrm{~cm}$ dengan konveyor rantai untuk mengangkut miniature mobil yang diparkir. Ladder diagram berisi perintah untuk memasukkan dan mengeluarkan mobil, serta menghitung jumlah mobil yang terparkir. Pada bagian antarmuka disematkan HMI untuk mempermudah pengoperasian. Pengujian prototipe dilakukan dengan cara memasukkan mobil secara urut sampai tempat parkir penuh kemudian dilanjutkan dengan simulasi masuk / keluar secara acak. Hasil pengujian menunjukkan prototipe sistem parkir telah bekerja sesuai dengan yang direncanakan.
\end{abstract}

Katakunci-Human Machine Interface; Programable Logic Control; Sistem Parkir Gantung Berputar

\section{Pendahuluan}

Dengan meningkatnya populasi manusia dan urbanisasi, kebutuhan lahan untuk perumahan, industri, dan pertanian menjadi semakin meningkat. Kondisi ini mengakibatkan kesulitan dalam mencari lahan parkir [1]. Di sisi lain, masyarakat yang mampu secara ekonomi cenderung untuk untuk membeli mobil pribadi yang digunakan sebagai alat transportasinya. Kenaikan jumlah mobil tersebut semakin menambah masalah perparkiran di lahan parkir yang sejak awal sudah terbatas.
Pemilik mobil sering kali memerlukan waktu yang lama hanya untuk mencari tempat parkir. Setelah tiba di tempat parkir, lalu lintas biasanya melambat karena pengemudi menurunkan laju mobilnya untuk mencari tempat parkir yang masih kosong sehingga menyebabkan antrian dan kemacetan lalu lintas yang berlebihan. Menemukan tempat parkir merupakan salah satu penyebab utama stres bagi pengemudi di banyak tempat seperti di kampus, kompleks perbelanjaan, pusat kota, dan gedung perkantoran.

Sistem parkir otomatis dapat mengurangi masalah perparkiran dengan memanfaatkan ruang fisik yang relatif lebih kecil untuk memarkir mobil secara mandiri. Ada beberapa jenis sistem parkir otomatis yaitu sistem rack \& rail, sistem lift \& slide, dan sistem rotary [2]. Dalam sistem parkir rotary, mobil masuk dan keluar tempat parkir di tempat yang sama. Setelah pengemudi meninggalkan zona aman, kendaraan akan diparkir secara otomatis dengan memutar seluruh struktur parkir dan menyediakan tempat masuk untuk mobil berikutnya. Mobil yang telah terparkir dapat diambil dengan mengklik tombol yang tersedia dan sistem akan memutar struktur parkir secara otonom sampai mobil yang dibutuhkan berhasil ditempatkan di pintu keluar sistem parkir dan siap diambil oleh pengemudi [3].

Permasalahan tersebut melatarbelakangi dilakukannya penelitian untuk membuat sebuah prototipe sistem parkir gantung berputar ke atas. Sistem parkir tersebut berbasis PLC (Programable Logic Control) sebagai kendali utamanya dengan penambahan HMI (Human Machine Interface). HMI merupakan jalur komunikasi antara manusia dan mesin [4]. Prototipe sistem parkir gantung berputar ke atas ini memiliki 6 slot tempat parkir dan terdapat 1 pintu masuk. Mekanisme alat ini yaitu berupa konveyor rantai yang dihubungkan dengan tempat parkir yang akan berputar ke atas dan ke bawah. Konveyor digerakkan dengan menggunakan motor listrik DC (Direct Current) yang terhubung dengan gearbox untuk meningkatkan torsi dan mengurangi kecepatan putar yang 
bertujuan untuk meringankan beban motor listrik DC pada saat memutar konveyor.

Motor DC merupakan salah satu dari rangkaian mesin listrik yang mengubah energi listrik arus searah menjadi energi mekanik [5]. Kontrol prototipe sistem parkir gantung menggunakan PLC. Sebuah PLC dapat diprogram untuk mengaktifkan dan mengontrol peralatan industri dan menggabungkan sejumlah pin I/O, yang memungkinkan sinyal listrik untuk dihubungkan. Perangkat input dan perangkat output dari proses terhubung ke PLC dan program kontrol dimasukkan ke dalam memori PLC [6].

Sistem parkir yang umum dijumpai saat ini masih dalam bentuk tradisional seperti model parkir di basement atau ruangan di bawah permukaan tanah dan parkir outdoor di luar ruangan yang keduanya membutuhkan area yang luas sehingga tidak efisien. Sistem parkir gantung berputar ke atas ini dirancang untuk menambah kapasitas ruang parkir mobil di area yang terbatas.

\section{Metode}

Perancangan sistem parkir gantung berputar ke atas ini meliputi tiga bagian yaitu perancangan sistem, tata letak perangkat keras, dan perancangan rangkaian elektronika. Diagram alir penelitian ditunjukkan pada Gambar 1 sedangkan diagram alir sistem parkir gantung berputar ke atas ditunjukkan pada Gambar 2.

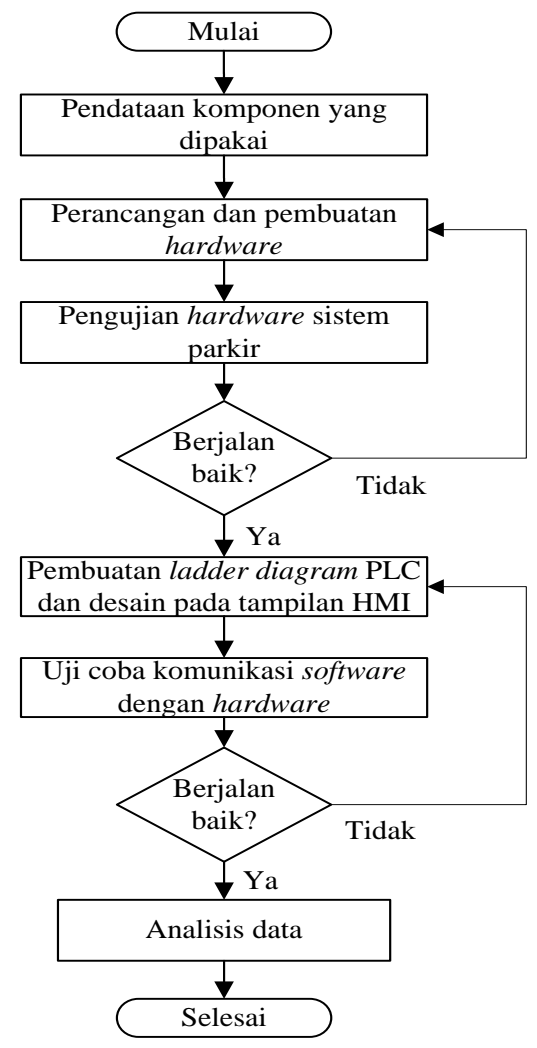

Gambar 1. Diagram alir penelitian

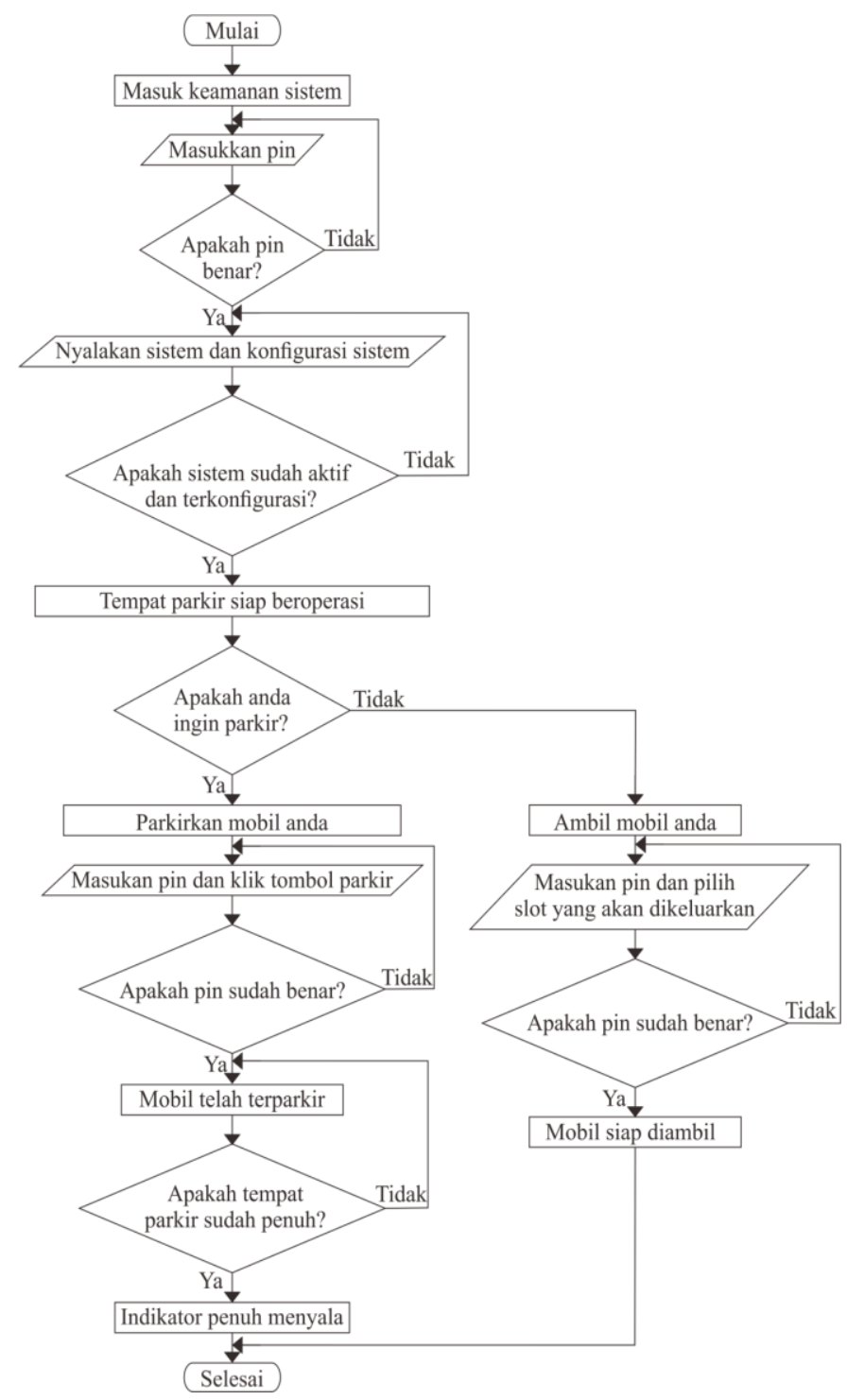

Gambar 2. Diagram alir sistem parkir gantung berputar ke atas

Blok diagram prototipe sistem parkir gantung berputar ke atas ditunjukkan pada Gambar 3. Prototipe tersebut menggunakan PLC, HMI, catu daya 220 VAC dan 12-24 VDC, sensor infrared, motor DC, dan limit switch. Pada saat akan parkir, PLC akan menerima perintah dari HMI untuk menggeser mobil yang telah diparkir kemudian menyiapkan slot tempat parkir selanjutnya yang masih kosong dengan bantuan limit switch ke 7 dan sensor infrared. Jika logika 1:0 artinya slot selanjutnya kosong, jika limit switch ke 7 dan sensor infrared dapat logika 1:1 artinya ada mobil di slot tersebut dan slot parkir akan terus bergeser hingga menemukan slot kosong atau berlogika 1:0. Limit switch ke 1, 2, 3, 4, 5, dan 6 yang sama dengan slot parkir ke 1, 2, 3, 4, 5, dan 6 akan berfungsi ketika mengeluarkan mobil dengan cara menyentuh nomor slot pada layar HMI. Tempat parkir akan terus bergeser hingga mobil di slot yang diinginkan siap untuk diambil. 


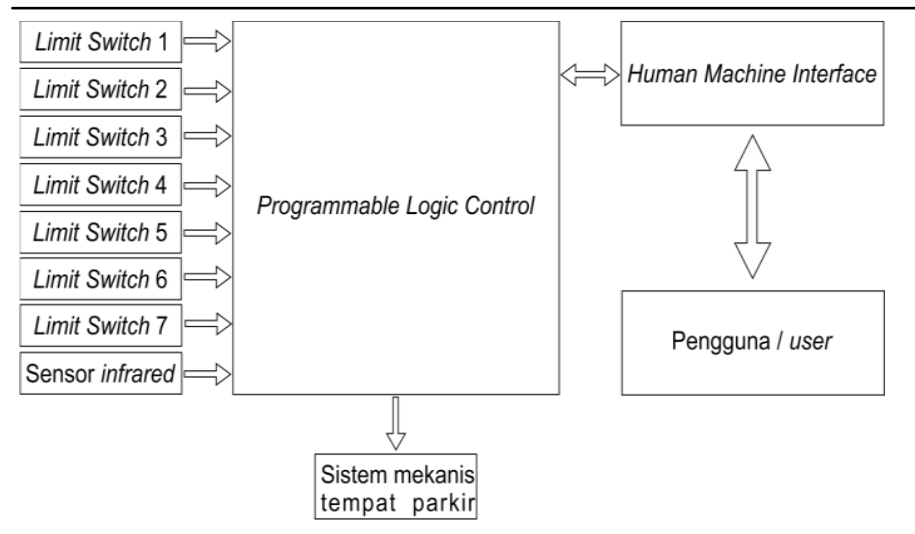

Gambar 3. Blok diagram sistem parkir gantung berputar ke atas

\section{HASIL DAN PEMBAHASAN}

\section{A. Hasil Desain HMI}

Perangkat lunak yang digunakan dalam mendesain HMI adalah NB-Designer. HMI didesain sedemikian rupa agar mempermudah dalam pengoperasian sistem parkir gantung berputar ke atas. Terdapat tiga alur kondisi desain yaitu alur desain saat mengaktifkan sistem parkir, alur desain saat mobil parkir dan alur desain saat mobil keluar.

Gambar 4 merupakan layar utama tampilan pada HMI yang terdiri dari ikon petir, parkir, keluar, dan jumlah mobil yang akan terhitung secara realtime.

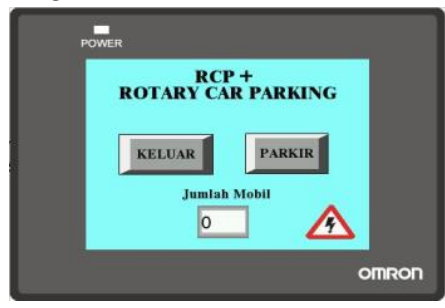

Gambar 4. Layar utama HMI

Saat menekan ikon petir akan diminta untuk memasukkan PIN kode keamanan sistem seperti ditunjukkan pada Gambar 5. PIN tersebut hanya diketahui oleh petugas khusus yang ditugaskan untuk mengontrol sistem parkir. Ketika PIN sudah dimasukkan maka akan berganti ke layar keamanan sistem dimana ada ikon tombol power, konfigurasi tempat parkir, lampu indikator sistem dan tombol kembali ke layar utama.

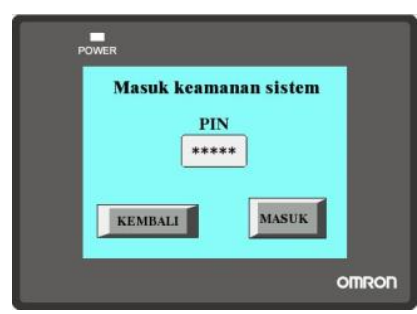

(a)

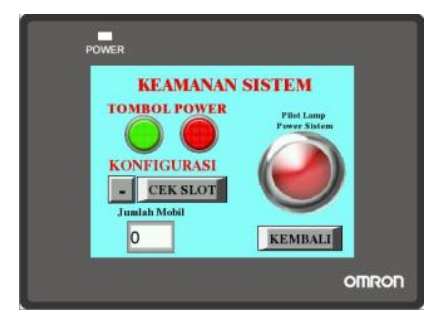

(b)
Gambar 5. (a) Tampilan saat akan masuk keamanan sistem (b) Tampilan saat sudah masuk keamanan sistem

\section{B. Instalasi Kabel}

Instalasi kabel dari prototipe sistem parkir gantung berputar ke atas ditunjukkan pada Gambar 6.
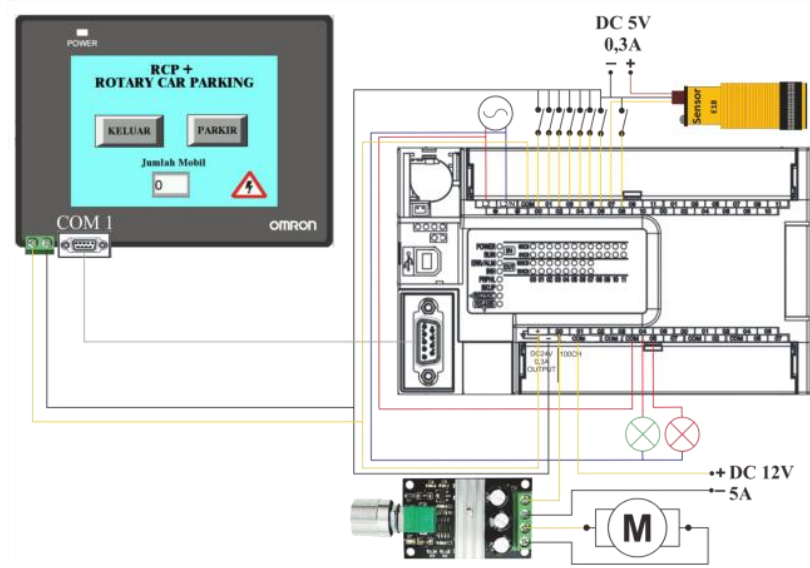

Gambar 6. Instalasi kabel sistem parkir gantung berputar ke atas

\section{Program Sistem Parkir Gantung Berputar Ke Atas}

Program dari sistem parkir gantung berputar ke atas dibuat dengan menggunakan software CX-Programmer dengan bahasa pemrograman berupa ladder diagram.

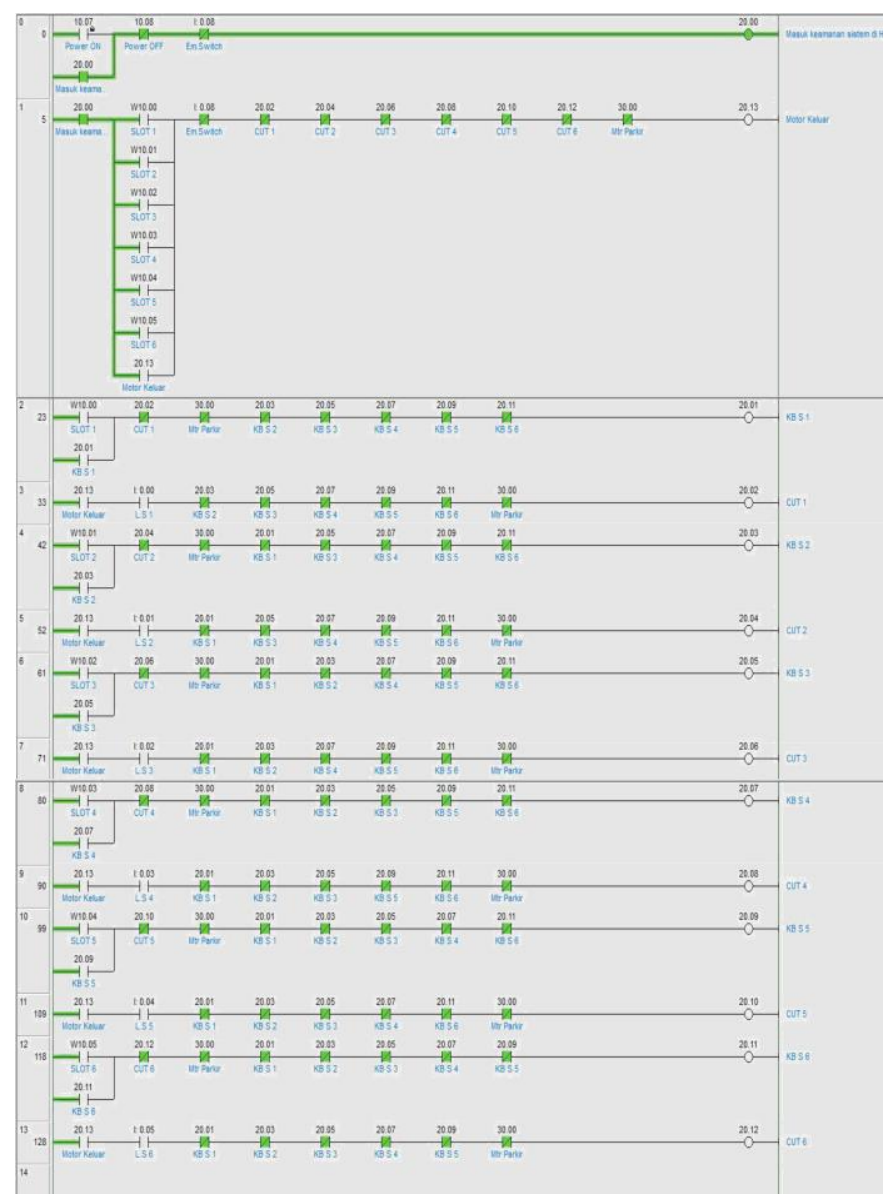

Gambar 7. Ladder diagram baris 0-14 
Ladder diagram baris ke-0 pada Gambar 7 berfungsi untuk mengaktifkan program, jika internal relay PLC 20.00 dapat masukan 1 maka seluruh program akan aktif. Baris ke 1-13 adalah program untuk mengeluarkan mobil pada slot tertentu. Alamat W10.00 (Slot 1), W10.01 (Slot 2), W10.02 (Slot 3), W10.03 (Slot 4), W10.04 (Slot 5) dan W10.05 (Slot 6) adalah alamat internal relay pada PLC yang akan diberi masukan data melalui HMI. Alamat input 0.00 (L.S 1), 0.01 (L.S 2), 0.02 (L.S 3), 0.03 (L.S 4), 0.04 (L.S 5) dan 0.05 (L.S 6) adalah input dari limit switch yang berjumlah enam buah dan berfungsi untuk memutus arus motor DC berdasarkan slot yang dipanggil. Alamat W10.00 (slot 1) tipe kontak normally open digunakan untuk memanggil mobil pada slot 1 , ketika diberi masukan 1 maka akan mengaktifkan alamat internal relay 20.13 (motor keluar), selanjutnya akan memicu alamat output 100.00 (output motor) yang terhubung ke motor DC. Motor DC akan berhenti jika sudah mengenai limit switch slot 1 pada alamat input 0.00 (L.S 1). Limit switch tersebut telah diberi sistem interlocking supaya masing-masing limit switch tidak bisa aktif secara bersamaan.

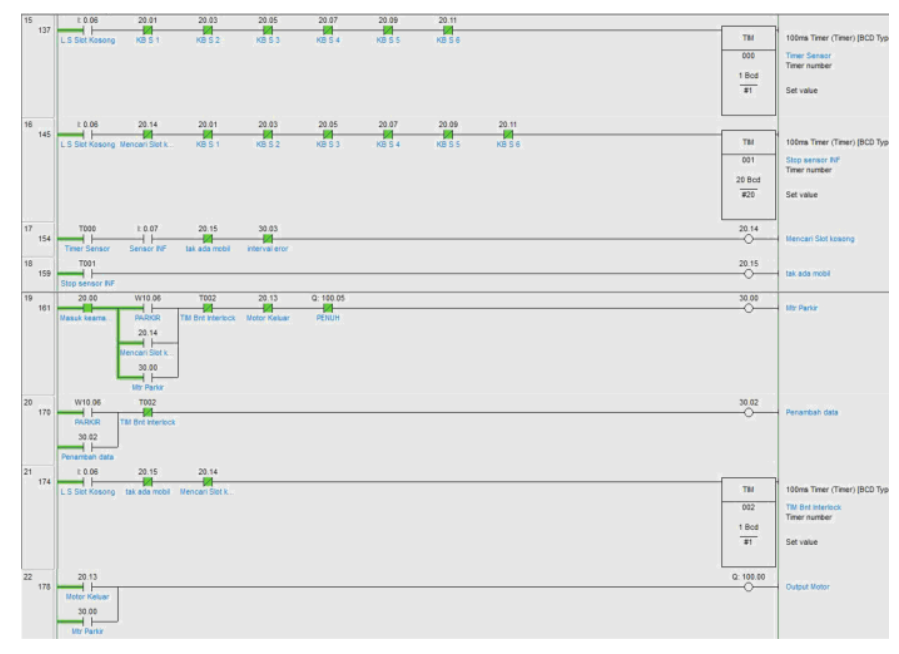

Gambar 8. Ladder diagram baris 15-22

Gambar 8 merupakan ladder diagram dari program untuk memarkirkan mobil. Alamat W10.06 (parkir) adalah alamat internal relay pada PLC yang akan diberi masukan data melalui HMI untuk mengaktifkan alamat internal relay 30.00 (motor parkir) dan selanjutnya akan memicu alamat output 100.00 (output motor) yang terhubung ke motor DC untuk memarkirkan mobil dan menyiapkan slot selanjutnya yang masih kosong. Alamat 0.06 (L.S slot kosong) dan 0.07 (Sensor INF) adalah dua alamat input yang terhubung dengan limit switch dan sensor infrared, kedua masukan tersebut saling berkaitan jika terdapat masukan 1:1 artinya terdapat mobil di slot berikutnya maka motor DC akan tetap berputar untuk menyiapkan slot yang masih kosong atau sampai mendapat masukan 1:0 yang artinya sensor infrared tidak mendeteksi mobil dan limit switch akan memutus arus motor DC melalui alamat T002.

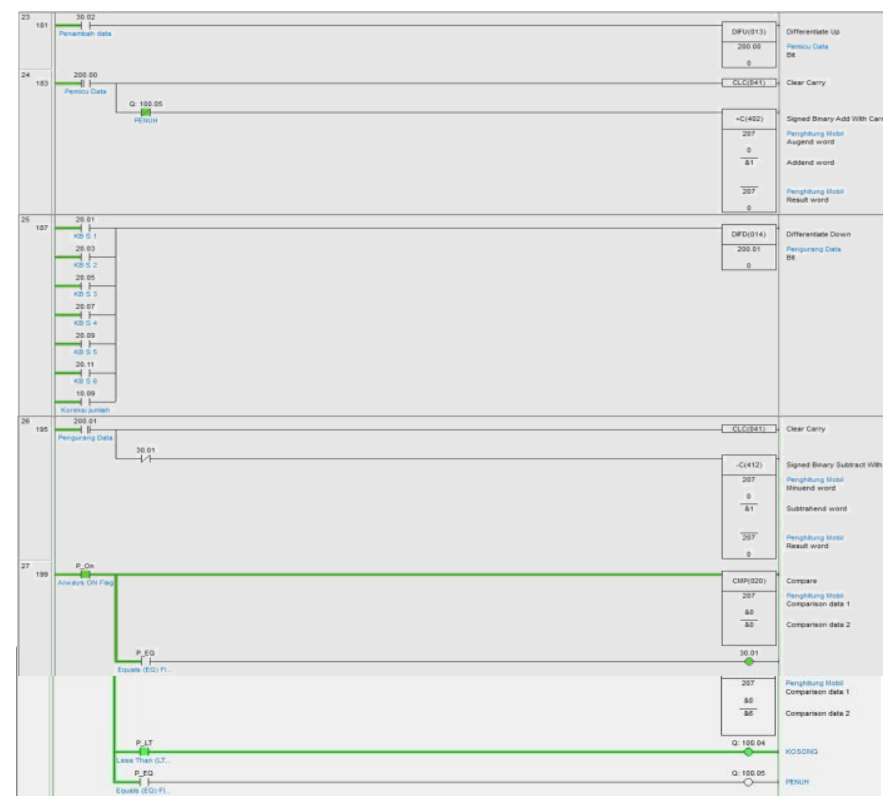

Gambar 9. Ladder diagram baris 23-27

Baris 23-27 adalah ladder diagram dari program yang berfungsi sebagai penambah data, pengurang data dan menampilkan lampu indikator merah atau hijau. Penambah data dipicu oleh alamat internal relay 30.02 pada Gambar 9, kemudian diteruskan oleh DIFU 200.00 yang akan memberi masukan data 1 bit pada alamat $+C$ 207. Pengurang data akan dipicu oleh alamat yang berhubungan dengan internal relay 20.13 (Motor Keluar) kemudian diteruskan oleh DIFD 200.01 yang akan memberi masukan data 1 bit pada alamat -C 207. Alamat + C 207 dan $-C 207$ selanjutnya akan diproses melalui instruksi CMP 207, jika terdapat penambahan 1 bit dalam alamat +C 207 sebanyak 4 kali maka pada instruksi CMP 207 akan menampilkan bilangan desimal berjumlah 4 , kemudian jika terjadi pengurangan data sebanyak 1 kali maka alamat $-\mathrm{C}$ 207 mendapat masukan 1 bit maka instruksi CMP 207 akan mengkomparasi dan mengubah jumlah menjadi 3 karena sudah terjadi proses pengurangan. Instruksi CMP 207 telah disetel untuk memberi batasan jumlah tidak lebih dari 6 dan tidak kurang dari 0 , jika jumlah penambahan sudah mencapai 6 maka lampu indikator akan menyala merah dan jika kurang dari 6 maka lampu indikator akan menyala hijau. Jumlah penambahan dan pengurangan bisa dilihat di layar HMI secara realtime.

\section{Bentuk Prototipe Sistem Parkir Gantung Berputar Ke Atas}

Prototipe sistem parkir gantung berputar ke atas seperti yang ditunjukkan pada Gambar 10 dibuat dengan menggunakan kerangka besi holo berdiameter $1,5 \times 3 \mathrm{~cm}$ dengan konveyor rantai untuk mengangkut miniature mobil yang hendak diparkir. Tampilan antar muka menggunakan HMI Omron tipe NB5Q-TW00B dan otak dari sistem parkir ini menggunakan PLC Omron tipe CP1E-N30. 


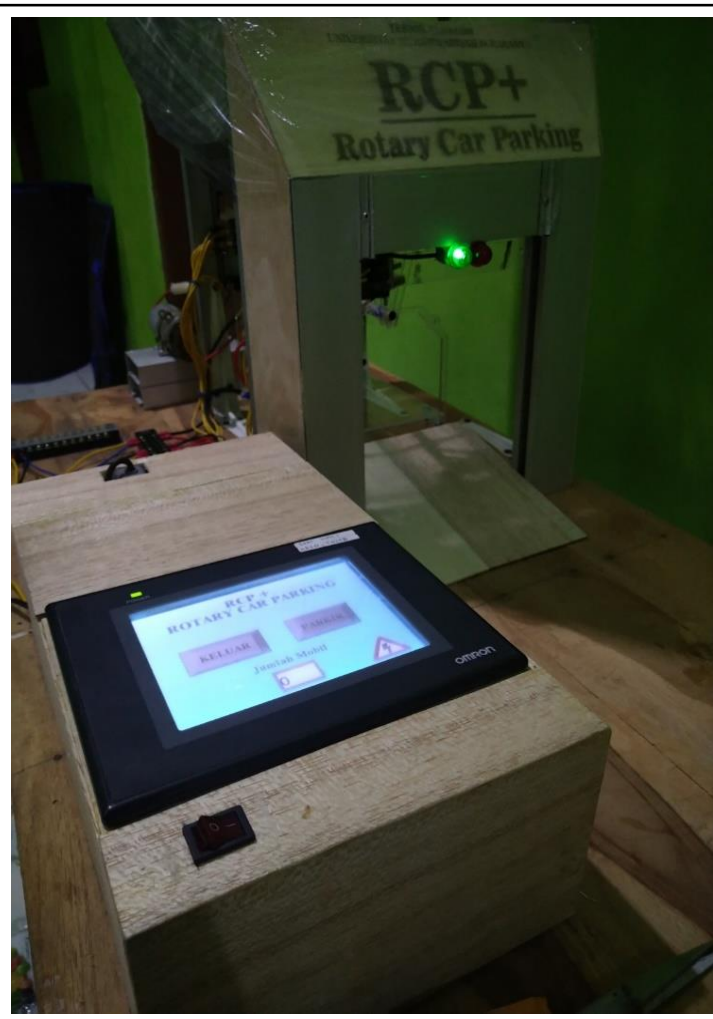

Gambar 10. Prototipe sistem parkir gantung berputar ke atas

\section{E. Hasil Pengujian Sistem Parkir Gantung Berputar Ke Atas}

Pengujian dilakukan dengan 3 variasi yaitu saat semua mobil masuk ke tempat parkir, saat sebagian mobil masuk dan sebagian mobil keluar dari tempat parkir secara acak, serta saat semua mobil keluar dari tempat parkir. Keseluruhan hasil pengujian sistem parkir ditunjukkan pada Tabel 1, Tabel 2 dan Tabel 3.

TABEL 1 HASIL PENGUJIAN SISTEM PARKIR SAAT MOBIL MASUK

\begin{tabular}{|c|c|c|c|c|c|}
\hline Mobil & Status & $\begin{array}{c}\text { No Tempat } \\
\text { Parkir }\end{array}$ & Mobil Terparkir & Jumlah & $\begin{array}{c}\text { Lampu } \\
\text { Indikator }\end{array}$ \\
\hline M1 & Masuk & 1 & M1 & 1 & Hijau \\
\hline M2 & Masuk & 2 & M1,M2 & 2 & Hijau \\
\hline M3 & Masuk & 3 & M1, M2, M3 & 3 & Hijau \\
\hline M4 & Masuk & 4 & M1, M2, M3, M4 & 4 & Hijau \\
\hline M5 & Masuk & 5 & M1, M2, M3, M4, M5 & 5 & Hijau \\
\hline M6 & Masuk & 6 & M1, M2, M3, M4, M5, M6 & 6 & Merah \\
\hline
\end{tabular}

Tabel 1 menunjukkan kondisi sistem parkir pada saat 6 buah mobil (M1 - M6) masuk ke tempat parkir secara berurutan sampai tempatnya penuh. Ketika pemilik mobil pertama M1 telah memasukkan kode keamanan (PIN) dan menekan tombol parkir maka sistem parkir akan berputar dan berhenti ketika slot nomer 1 telah berada di depan pintu parkir. Mobil berikutnya yang hendak parkir adalah mobil kedua M2. Ketika pemilik mobil telah memasukkan PIN dan menekan tombol parkir maka sistem parkir berputar dan berhenti di slot parkir nomer 2. Slot parkir nomer 3 tersedia ketika mobil ketiga M3 hendak masuk ke tempat parkir. Proses ini akan diulangi lagi sampai semua tempat parkir telah terisi. Lampu indikator hijau akan terus menyala ketika mobil M1 sampai M5 telah terparkir dan berubah menjadi merah setelah mobil M6 telah terparkir. Warna hijau menunjukkan tempat parkir masih tersedia sedangkan warna merah menunjukkan tempat parkir telah terisi penuh. Prototipe sistem parkir didesain mampu menampung 6 buah mobil sehingga ketika mobil ke-6 telah terparkir maka lampu indikator berubah menjadi merah. Hasil pengujian menunjukkan sistem parkir telah bekerja sesuai dengan yang direncanakan.

TABEL 2 HASIL PENGUJIAN SISTEM PARKIR SAAT MOBIL MASUK KELUAR

\begin{tabular}{|c|c|c|c|c|c|}
\hline Mobil & Status & $\begin{array}{c}\text { No Tempat } \\
\text { Parkir }\end{array}$ & Mobil Terparkir & Jumlah & $\begin{array}{c}\text { Lampu } \\
\text { Indikator }\end{array}$ \\
\hline M3 & Keluar & 3 & M1, M2, M4, M5, M6 & 5 & Hijau \\
\hline M6 & Keluar & 6 & M1, M2, M4, M5 & 4 & Hijau \\
\hline M4 & Keluar & 4 & M1, M2, M5 & 3 & Hijau \\
\hline M5 & Keluar & 5 & M1, M2 & 2 & Hijau \\
\hline M7 & Masuk & 5 & M1, M2, M7 & 3 & Hijau \\
\hline M8 & Masuk & 6 & M1, M2, M7, M8 & 4 & Hijau \\
\hline M1 & Keluar & 1 & M2, M7, M8 & 3 & Hijau \\
\hline M9 & Masuk & 1 & M2, M7, M8, M9 & 4 & Hijau \\
\hline M10 & Masuk & 3 & M2, M7, M8, M9, M10 & 5 & Hijau \\
\hline
\end{tabular}

Tabel 2 merupakan hasil pengujian sistem parkir pada saat mobil masuk keluar tempat parkir secara acak. Pengujian ini merupakan kelanjutan dari pengujian yang sebelumnya dimana 6 buah mobil telah terparkir. Pertama kali mobil M3 hendak keluar dari tempat parkir. Ketika pemilik mobil telah menekan tombol keluar, memasukkan PIN dan memilih nomer tempat parkir mobilnya maka sistem parkir akan berputar secara otomatis dan berhenti ketika mobil M3 telah berada di depan pintu parkir. Ketika mobil M3 telah keluar dari tempat parkir maka lampu indikator yang semula berwarna merah akan berubah menjadi berwarna hijau. Mobil berikutnya yang hendak keluar adalah mobil M6. Sistem parkir berputar lagi dan berhenti ketika slot parkir nomer 6 tepat berada di depan pintu parkir. Proses ini diulangi lagi ketika mobil M4 dan M5 keluar dari tempat parkir. Setelah itu mobil ketujuh M7 hendak masuk ke tempat parkir. Sistem parkir akan berputar dan mencari slot parkir yang kosong dan ternyata berhenti ketika slot nomer 5 yang kosong tepat berada di depan pintu parkir. Proses yang sama terjadi ketika mobil kedelapan M8 hendak masuk ke tempat parkir. Sistem menyediakan slot parkir nomer 6 yang kosong sebagai tempat parkirnya. Prototipe sistem parkir tetap bekerja dengan baik untuk pengujian yang berikutnya yaitu ketika mobil pertama M1 keluar dari tempat parkir, mobil kesembilan M9 masuk ke tempat parkir dan mobil kesepuluh M10 masuk ke tempat parkir. Di bagian akhir dari pengujian ini, terdapat 5 buah mobil yang terparkir. Hasil pengujian ini menunjukkan bahwa sistem parkir telah bekerja sesuai dengan yang direncanakan. 
TABEL 3 HASIL PENGUJIAN SISTEM PARKIR SAAT MOBIL KELUAR

\begin{tabular}{|c|l|c|c|c|c|}
\hline Mobil & Status & $\begin{array}{c}\text { No Tempat } \\
\text { Parkir }\end{array}$ & Mobil Terparkir & Jumlah & $\begin{array}{c}\text { Lampu } \\
\text { Indikator }\end{array}$ \\
\hline M2 & Keluar & 2 & M7, M8, M9, M10 & 4 & Hijau \\
\hline M9 & Keluar & 1 & M7, M8, M10 & 3 & Hijau \\
\hline M8 & Keluar & 6 & M7, M10 & 2 & Hijau \\
\hline M7 & Keluar & 5 & M10 & 1 & Hijau \\
\hline M10 & Keluar & 3 & - & 0 & Hijau \\
\hline
\end{tabular}

Tabel 3 merupakan hasil pengujian sistem parkir pada saat semua mobil keluar dari tempat parkir. Pengujian ini merupakan kelanjutan dari pengujian sebelumnya dimana 5 buah mobil masih terparkir. Pada pengujian ini, kelima mobil tersebut akan keluar dari tempat parkir. Mobil yang keluar pertama kali adalah mobil M2. Ketika pemilik mobil M2 telah mengikuti prosedur maka sistem parkir akan berputar dan berhenti ketika slot parkir nomer 2 tepat berada di depan pintu parkir. Mobil berikutnya yang akan keluar parkir adalah M9 yang terparkir di slot nomer 1. Setelah pemilik mobil mengikuti prosedur maka sistem parkir akan berputar dan berhenti ketika slot parkir nomer 1 tepat berada di depan pintu parkir. Prototipe sistem parkir bekerja dengan baik ketika mobil yang tersisa hendak keluar dari tempat parkir yaitu mobil M8, M7, dan M10. Hasil pengujian ini menunjukkan bahwa prototipe sistem parkir gantung berputar ke atas telah bekerja sesuai dengan rencana yang telah diharapkan.

\section{Penutup}

Berdasarkan dari hasil penelitian yang telah dilakukan, dapat ditarik kesimpulan sebagai berikut:

1. Prototipe sistem parkir gantung berputar ke atas telah bekerja dan berfungsi sesuai dengan yang direncanakan ketika diuji saat mobil masuk, masuk keluar dan keluar dari tempat parkir.

2. Prototipe sistem parkir gantung berputar ke atas yang didesain dapat menampung enam mobil, memiliki satu pintu untuk keluar / masuk mobil, terdapat lampu indikator sebagai petunjuk penuh atau kosong, dan memiliki tombol emergency switch.

3. Menu keamanan sistem parkir digunakan untuk mengaktifkan ladder diagram dan mengatur konfigurasi slot parkir jika terjadi kesalahan pada perhitungan jumlah mobil.

\section{DAFTAR PUSTAKA}

[1] H. Rehborn, B. S. Kerner, and R.P Sch“afer. (2012). "Traffic jam warning messages from measured vehicle data with the use of three-phase traffic theory”. Adv. Microsystems for Automotive Applications 2012, pp. 241-250, Springer Berlin Heidelberg

[2] W. Wang, Y. Song, J. Zhang, and H. Deng. (2014). “Automatic parking of vehicles: A review of literatures". Int. J. Of Automotive Technology, 15(6):967-978, Oct 2014.
[3] G. Serpen and C. Dou. (2015). "Automated robotic parking systems: realtime, concurrent and multi-robot path planning in dynamic environments". Applied Intelligence, 42(2):231-251, Mar 2015.

[4] Gomez-Gil, Jaime, dkk. (2011). Steering a tractor by means of an EMGbased human-machine interface. Department of Signal Theory, Communications and Telematics Engineering, University of Valladolid

[5] Azman, M.A.H, dkk. (2018). A comparative study of fuzzy logic controller and artificial neural network in speed control of separately excited DC motor. Universiti Teknologi MARA.

[6] Patti, Sanjeev Kumar. (2016). "Automation of belt conveyor system. International Journal of Emerging Technology in Computer Science \& Electronics (IJETCSE), 23(6) - October 2016 (Special Issue) 